\title{
ENERGY EFFICIENCY OF WORM GEAR DRIVES
}

\author{
Antoaneta Dobreva \& Petyr Pavlov
}
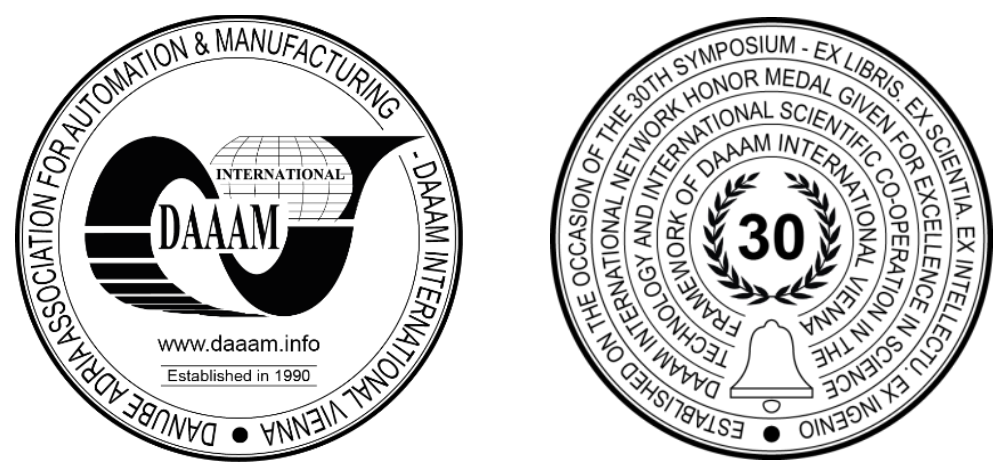

This Publication has to be referred as: Dobreva, A[ntoaneta] \& Pavlov, P[etyr] (2021). Energy Efficiency of Worm Gear Drives, Proceedings of the 32nd DAAAM International Symposium, pp.0110-0116, B. Katalinic (Ed.), Published by DAAAM International, ISBN 978-3-902734-33-4, ISSN 1726-9679, Vienna, Austria DOI: $10.2507 / 32$ nd.daaam.proceedings.016

\begin{abstract}
A theoretical investigation of cylindrical worm gear drives in the field of energy efficiency is presented. The research objective is to analyse and determine the possibilities for a selection of worm gear drives with maximum energy efficiency at the initial stage of the design process within the technical and design requirements set up. An optimisation study of worm gear drives has been implemented, based upon several groups of criteria: tribological, strength, kinematic and geometry parameters. The main research criterion determined is the maximum gearing efficiency. Scientific methods have been applied, which consistently determine the influence of different groups of criteria mentioned. A database of the obtained calculation results is structured. Different graphical relationships show the dependencies between the relevant tribological, kinematic, strength and geometric parameters of the worm gear drives. The analysis of the results indicates the most advantageous areas of application for worm gear drives according to the main optimisation criterion selected. Important relationships and recommendations are suggested.
\end{abstract}

Keywords: energy efficiency; worm gear drives; gearing efficiency coefficients; tribology approach; optimisation research.

\section{Introduction}

The research of worm gear drives is a particularly important issue. Its solution is directly related to the improvement of the strategy for the modern development of mechanical engineering in order to increase the competitiveness of the sector. Improving the energy efficiency and the functional capability of worm gear drives are significant research problems for the scientific and academic staff. The research problem of improving the performance of the worm gear drives is also an interdisciplinary problem. Its solution is possible through the application of modern methods and approaches.

The calculation of the efficiency of a system requires the knowledge of either the power input and power loss, or the power input and power output. With regard to gearboxes, the overall power loss can be described as the sum of partial power losses of the gearbox components. They are caused mainly by the gears, bearings and by contacting seals. Gear losses generally cause a significant proportion of the overall power loss. Friction within the contact of two tooth flanks relates to the applied load of the tooth system and results in load-dependent gear losses. Churning losses, squeezing losses, impulse losses and ventilation losses are related to the oil flow in the gearbox [1]. They are referred to as no-load gear losses as they are almost independent from the applied load. 


\section{Theoretical background}

Worm gear drives are usually required at torque conversions with high gear ratio, at compact installation space and 90-degree axis-crossing angle. Due to their high-power density and sliding speeds within the tooth contact, frictional heat and thermal stresses are relatively high [1]. Therefore, the prediction of energy efficiency coefficients of gearboxes containing one or more worm gear stages is very important, especially during the design phase. However, determining the optimal geometry parameters is a complex problem, as they have to meet all the constraints, practical limitations and rules defined in the corresponding design case, [2], [3] and [4]. Some important transmission components have been successfully analysed aiming to improve their functional parameters with the help of modern methods and approaches. Important basic influencing parameters have also been defined, [5], [6] and [7]. Significant contributions concerning mathematical modelling of the tooth contact of worm gears have been developed by Niemann [8] and Weber [9]. Important tribological research activities have been performed by Wilkesmann [10], concerning elasto-hydrodynamic lubrication (EHL) calculations for different worm tooth geometries and by Predki [11], concerning significant parameter studies. Considerable parts of these investigations formed the basis of DIN 3996: 2019-09, [12].

Bouché [13] formulated a physics-based model for the calculation of the coefficient of friction for worm gears. The USA standard [14] recommends the important analytical relationships for estimating the coefficient of friction in the meshing for a hardened steel worm (58 HRC minimum), smoothly ground, or polished, or rolled, or with an equivalent finish, operating on a bronze worm gear. The approach for selecting the values of friction coefficient is explained in details in [15]. It depends on the sliding velocity in the worm gear drive.

Magyar [16] has made some research contributions, concerning the dynamics of worm gears and has derived a tribological calculation model for the calculation of the coefficient of friction, which is applied for the calculation of worm gear efficiency in [17]. Monz [18] and Mautner et al. [19] have made interesting investigations about the load capacity and efficiency of worm gears lubricated by consistent grease. They have used a specific Thermal Network Method for heat balance calculations, which correspond closely to the measurements.

Since worm gears show different gear losses, depending on the direction of the power flow, the calculation of the meshing efficiency must be considered separately. When the worm shaft is driving, according to DIN 3996:2019-09 [12], the meshing efficiency coefficient depends upon the reference lead (pitch) angle and the tooth friction angle. Beside geometrical and operational data such as gear ratio $u$, worm wheel torque $T_{2}$, worm shaft drive speed $n_{1}$ and reference pitch (lead) angle of the worm, the calculation of the load-dependent gear losses depends on the mean coefficient of friction. When the worm wheel is driving, the efficiency is generally lower. Furthermore, a self-locking effect can occur in this operation mode if the meshing efficiency coefficient is less than 0.5 , according to [12].

The mean coefficient of friction represents the complex friction characteristic of meshing tooth flanks by one single mean value. In the area of worm gear drives, there are currently several different approaches and calculation models available. DIN 3996:2012-09 [20] describes a simpler, empirical model, while Oehler et al. [21] \& [22] present a more detailed and complicated method. The latter was standardized in DIN 3996:2019-09 [12], replacing the simpler approach in DIN 3996:2012-09 [20] very recently.

As already discussed, the efficiency calculations for worm drives are standardized in AGMA 6034-B92 [14], BS 721 [23] and DIN 3996 [12]. The author's team completed successfully some research tasks in the field of energy efficiency in the area of gear drives and machine science. The results of these investigations are described in details in the following publications: [24], [25], [26], [27] and [28]. Based upon the literature publications studied, the authors' team focused on the following research objective: to analyse and determine the possibilities for selecting worm gear drives with maximum meshing efficiency coefficient at the initial stage of the design process within the technical requirements set up.

\section{Research methods}

A scientific methodology is applied, in which an optimisation investigation is successively performed within the following several stages:

The first stage includes the definition of the groups of criteria, according to which the optimisation investigation will be performed: tribological (gearing efficiency coefficient, tooth friction coefficient) and strength: determination of the nominal bending stresses in the gear profile of the worm wheel. The gearing friction coefficient is determined by the method described in details in Mott [15] and AGMA [14]. Bending strength calculations are determined by the methods of Niemann [1], [8] and [10].

The second stage of the research methodology includes tribological and strength calculations based upon different values of the kinematic parameters (gear ratio, worm shaft drive speed and sliding speed) and different values of the geometry parameters (module, center distance).

The third stage involves structuring a database of the calculation results obtained. Different graphical dependences are represented, showing the dependences between the relevant tribological, kinematic, strength and geometrical parameters of the worm gear drives.

The fourth stage of the research methodology aims to determine the main criterion of the optimisation investigation, which, according to the authors' team, is the gearing efficiency coefficient. The analysis of the results indicates the optimal areas of application for worm gear drives, according to the main optimisation criterion selected.

Significant relationships and recommendations are to be suggested. 


\section{Research results and discussion}

The optimisation research has been implemented on the criteria of sliding speed and gearing efficiency coefficient. It turns out that the influence of the worm gear module is particularly significant. Fig. 1 shows the variation in the sliding speed and the gearing efficiency when the module of the worm gear increases. The alterations of the indicated parameters at different numbers of starts of the worm $\mathrm{z}_{1}=4, \mathrm{z}_{1}=2$ and $\mathrm{z}_{1}=1$ are also shown. The results described graphically in the indicated figures are obtained at center distance $\mathrm{a}=200 \mathrm{~mm}$ and worm shaft drive speed $\mathrm{n}_{1}=700 \mathrm{rpm}$.

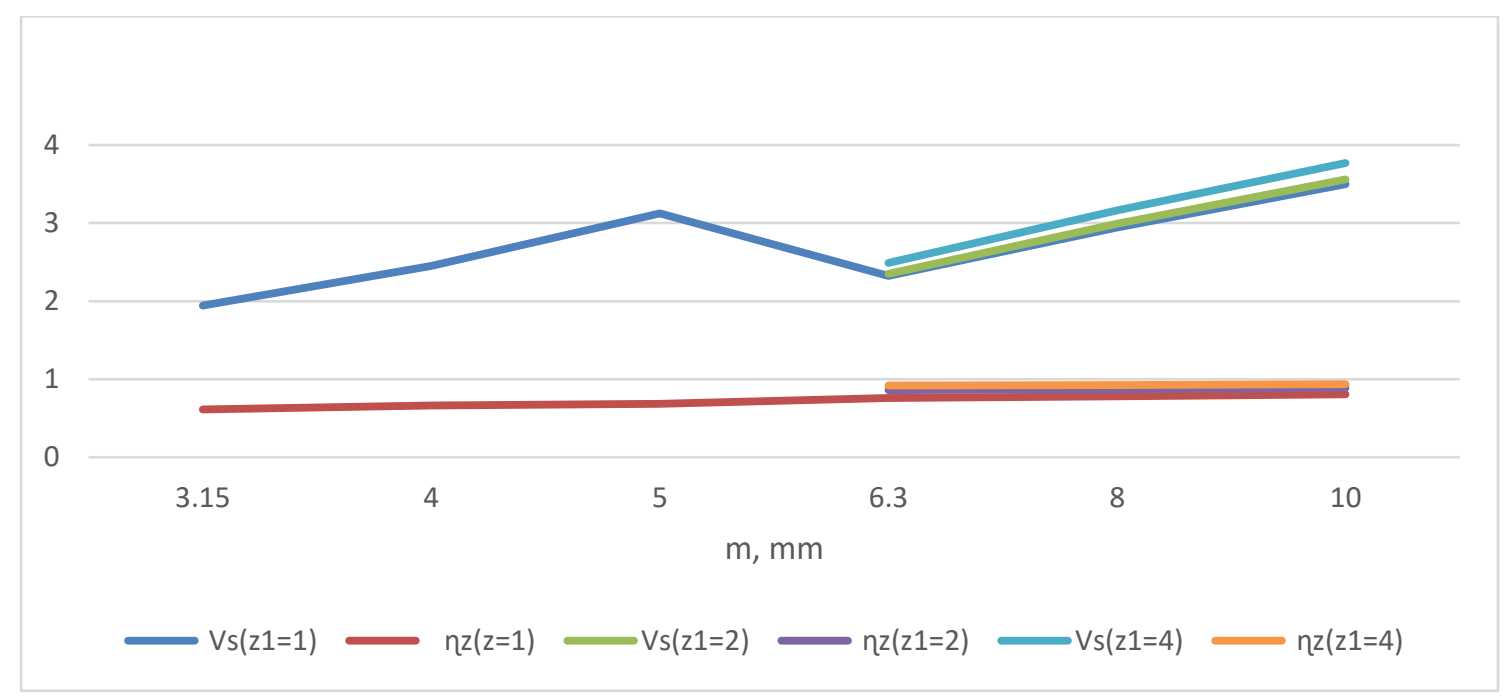

Fig. 1. Variation of sliding speed and gearing efficiency coefficient depending on the module

For a specific centre distance, the best gearing efficiency coefficient values are achieved at modules between the following boundaries: 6.3 and $10 \mathrm{~mm}$. With a larger number of worm starts, there is a slight increase in the gearing efficiency coefficient when the other geometry and kinematic parameters do not change.

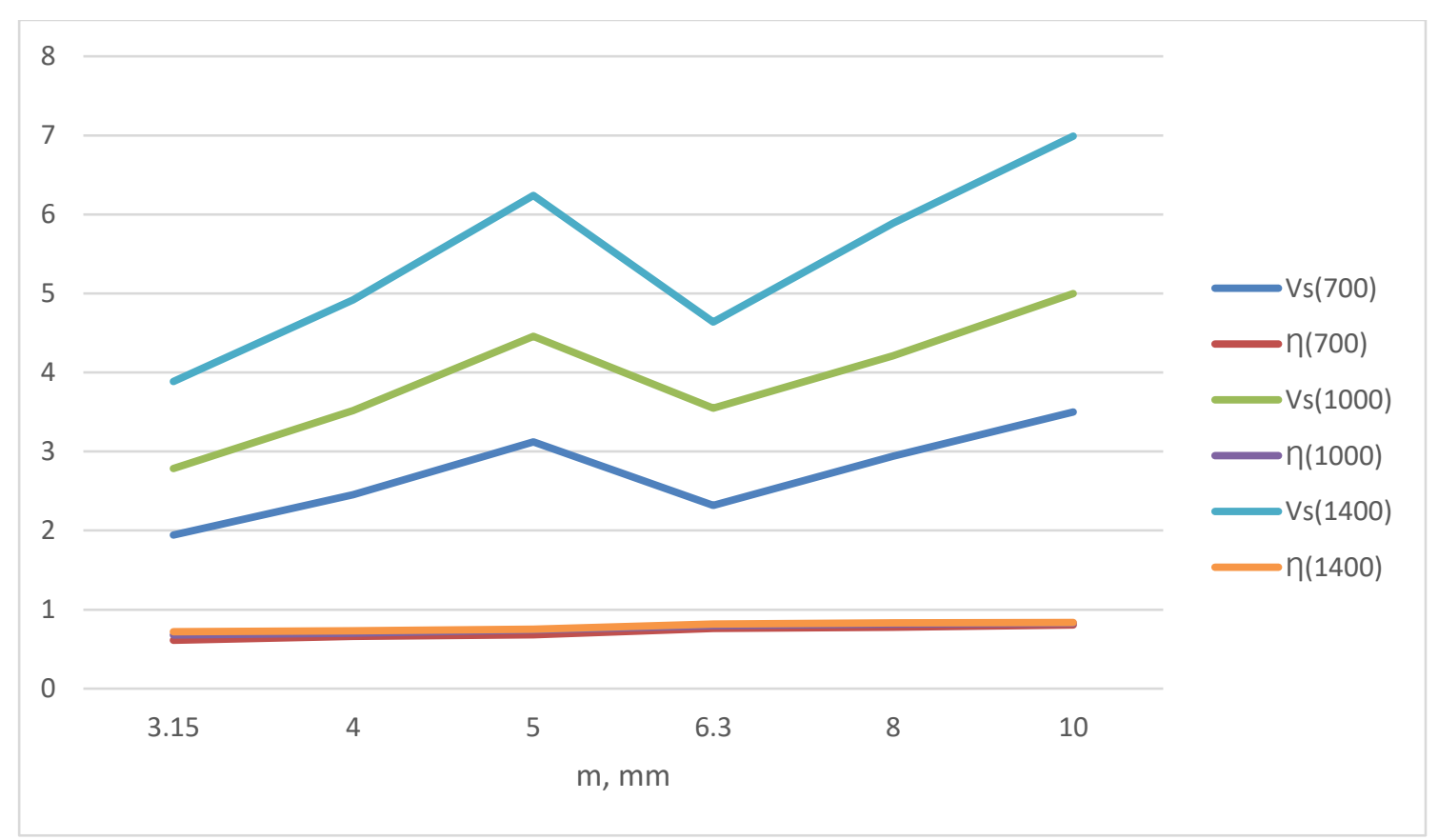

Fig. 2. Variation of sliding speed and gearing efficiency depending on the module and worm shaft drive speed

The graphical representations on Fig. 2 show the variations of the gearing efficiency coefficient and the sliding speed as functions of the values of the module and the worm shaft drive speed. It can be concluded that the gearing efficiency increases - although insignificantly - with increasing the worm shaft drive speed at equal geometry parameters of the worm gear drives. The influence of the worm shaft drive speed upon the sliding speed is much more clearly represented, as the speed of sliding increases with the increase of the rotational speed of the worm shaft. 


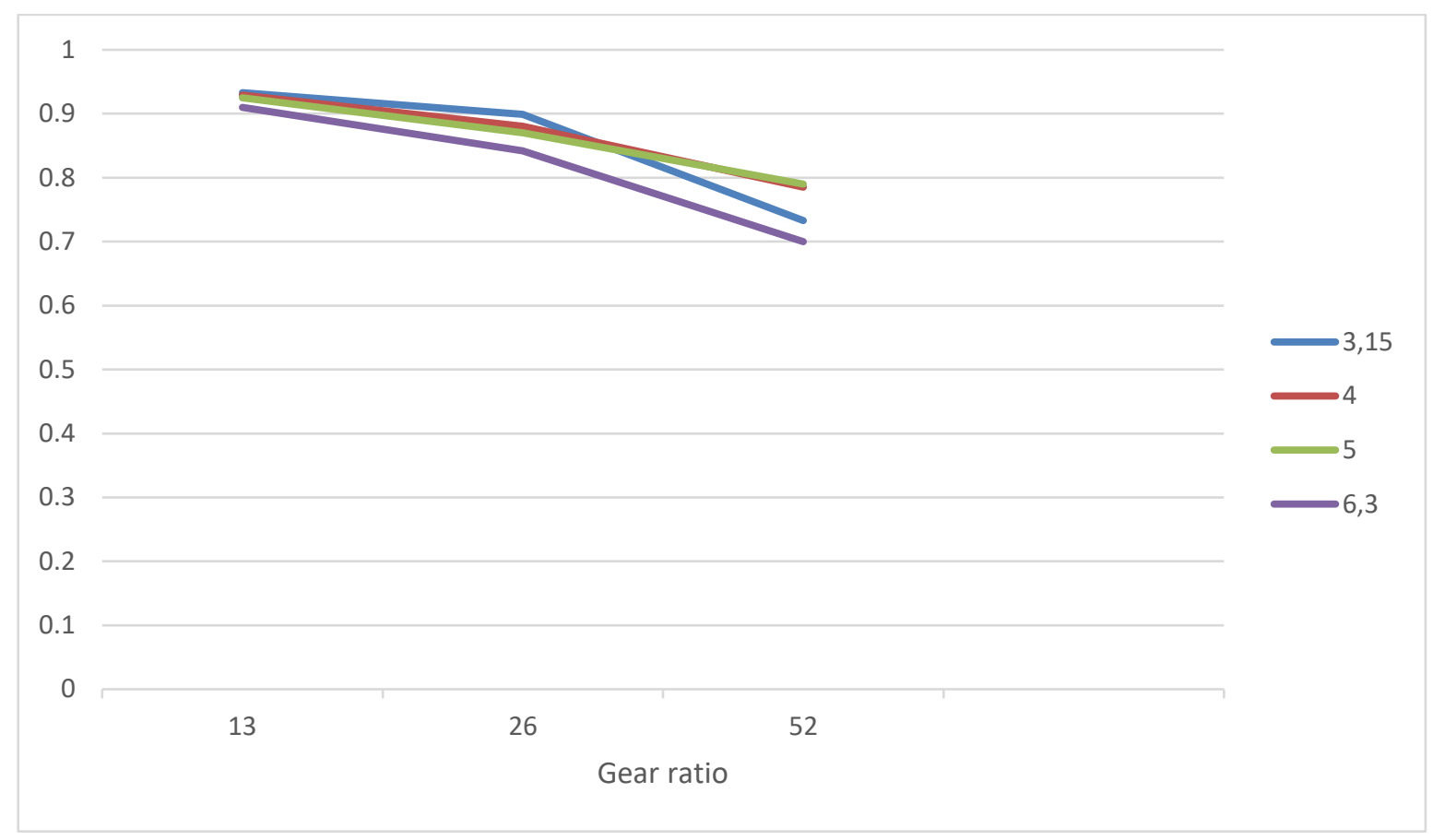

Fig. 3. Variation of gearing efficiency coefficient as a function of the module and the gear ratio

The graphical curves on Fig. 3 show the changes in the gearing efficiency coefficient depending on the values of the module and the values of the gear ratio at a centre distance $\mathrm{a}=125 \mathrm{~mm}$ and at worm shaft drive speed $\mathrm{n}=1500 \mathrm{rpm}$. It can be observed that the influence of the ratio on the gearing efficiency is much more significant in comparison with the influence of the factor "worm shaft drive speed". The application of lower gear ratios (up to $i=26$ ) leads to optimal values of gearing efficiency coefficients.

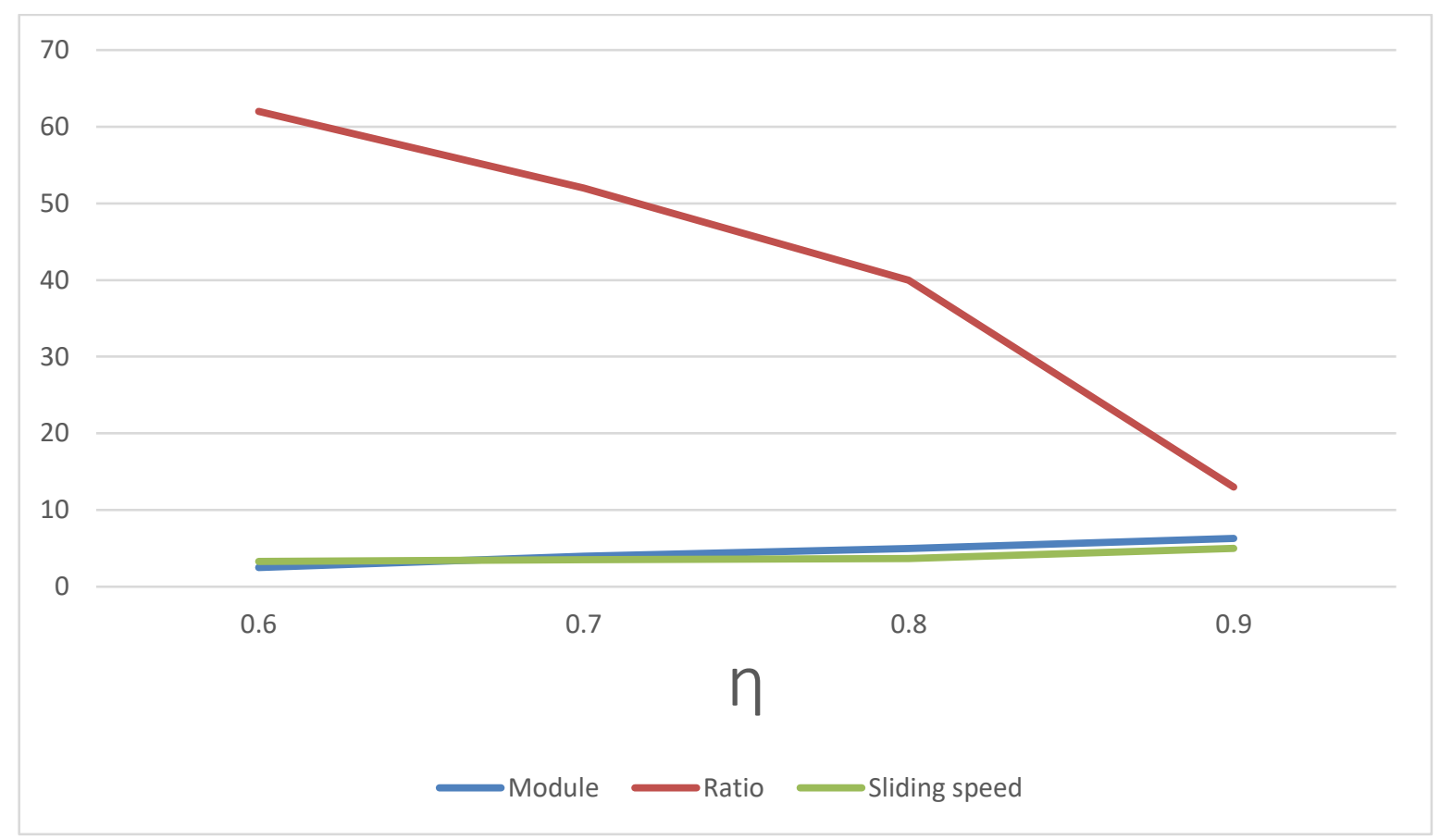

Fig. 4. Influence of the module, the gear ratio and the sliding speed

The representations on Fig. 4 show the simultaneous influence of the module, the gear ratio and the sliding speed to the gearing efficiency coefficient values at the center distance $\mathrm{a}=125 \mathrm{~mm}$ and at the worm shaft drive speed $\mathrm{n}=1500$ $\mathrm{rpm}$. The tendency for an abrupt increase of the gearing efficiency coefficient with a decrease in the gear ratio is especially clear. 
1.2

1

0.8

0.6

0.4

0.2

0

\begin{tabular}{lrrrrrrrrr}
4.83 & 7.25 & 10 & 13 & 14.5 & 20 & 26 & 29 & 40 & 52 \\
& \multicolumn{9}{c}{ Gear ratio }
\end{tabular}

$\longrightarrow \mathrm{m} 4 \longrightarrow \mathrm{m} 5=\mathrm{m} 6,3$

Fig. 5. Influence of the module and the gear ratio on the gearing efficiency

Fig. 5 shows the simultaneous influence of the module, the gear ratio and the sliding speed on the gearing efficiency coefficients at a centre distance $\mathrm{a}=125 \mathrm{~mm}$ and at a worm shaft drive speed $\mathrm{n}=1500 \mathrm{rpm}$. The analysis of the results shows that the most diverse kinematic possibilities are obtained when using gear ratios in the range from 10 to 26 while maintaining very good values of gearing efficiency, higher than 0.8 .

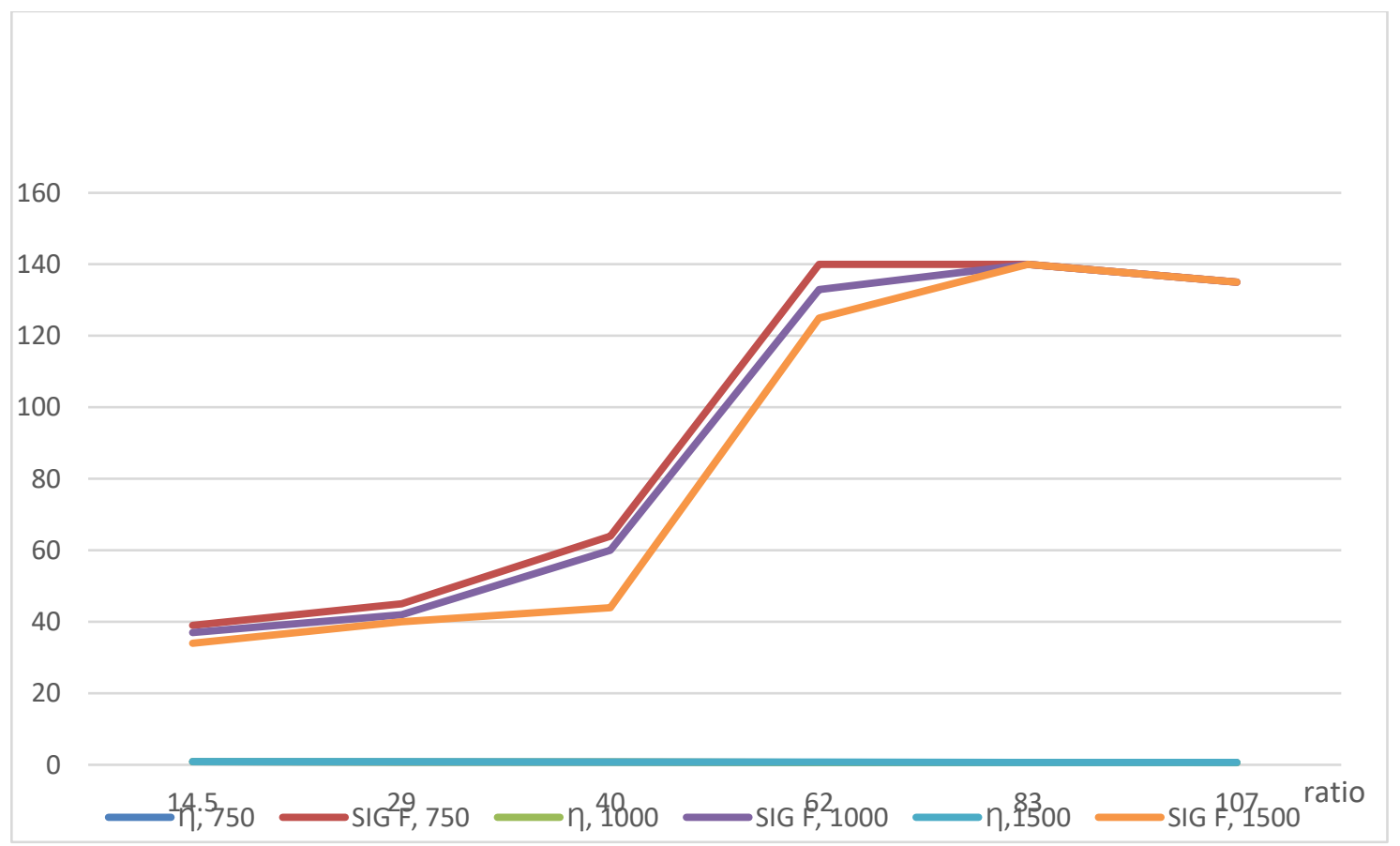

Fig. 6. Influence of kinematic parameters on gearing efficiency and bending stresses

The graphical curves in Fig. 6 show the change of the calculated maximum bending stresses of the gear profile of the worm wheel at nominal torque, taking into account the influence of the gear ratio, the rotational speed of the worm shaft on the gearing efficiency at centre distance $\mathrm{a}=125 \mathrm{~mm}$ and at worm shaft speeds $\mathrm{n}_{1}=750,1000$ and $1500 \mathrm{rpm}$. The analysis of the results shows that the optimal values of bending stresses and gearing efficiency are obtained when using gear ratios in the range up to 40 . 


\section{Conclusions}

The worm gear efficiency coefficient is highly dependent and its ways of optimisation are the problem to be solved in this paper. An optimisation study of worm gear drives is presented. Several groups of criteria have been applied: tribological, kinematic and load capacity. Calculations and analyses of the results have been performed. The influence of the gear ratio, module and the rotational speed of the worm shaft on the meshing efficiency in the worm gearing and the variation of the values of the bending stresses have been established.

The graphical representations show the variations of the gearing efficiency coefficient and the sliding speed as functions of the values of the module and the worm shaft drive speed. It can be concluded that the gearing efficiency increases - although insignificantly - with increasing the worm shaft drive speed at equal geometry parameters of the worm gear drives. The results show the changes in the gearing efficiency coefficient, depending on the values of the module and the values of the gear ratio. It can be observed that the influence of the ratio on the gearing efficiency is much more significant in comparison with the influence of the factor "worm shaft drive speed". The application of lower gear ratios (up to $i=26$ ) leads to optimal values of gearing efficiency coefficients. The tendency for an abrupt increase of the gearing efficiency coefficient with a decrease in the gear ratio is especially clear. The analysis of the results shows that the most diverse kinematic possibilities are obtained when using gear ratios in the range from 10 to 26 while maintaining very good values of gearing efficiency, higher than 0.8 . The results show the change of the calculated maximum bending stresses of the gear profile of the worm wheel at nominal torque, taking into account the influence of the gear ratio and the rotational speed of the worm shaft on the gearing efficiency. The analysis of the results shows that the optimal values of bending stresses and gearing efficiency are obtained when using gear ratios in the range up to 40.

The influence of the worm shaft drive speed upon the sliding speed is much more clearly represented. The speed of sliding increases with the increase of the rotational speed of the worm shaft. The results obtained can be used at an early stage of a design process of worm gear drives, allowing the designer to choose the optimal parameters in terms of maximum gearing efficiency coefficients in worm gear drives. Due to the small number of criteria used, this paper gives only the main dependencies of the worm gear set. The approach is to be optimised as well, showing how all criteria together influence the efficiency.

The future work on this topic is to involve more criteria into the research in order to determine in higher detail their influence on the maximisation of the gear efficiency coefficient. Three-dimensional graphical representations are to be created. These diagrams will contribute to facilitating the decision-making process, concerning the selection of the optimal worm gear drive in view of the energy efficiency within the relevant design assignment.

\section{Acknowledgments}

The authors acknowledge the financial support from the Scientific Research Funds of the University of Ruse, Bulgaria. The research work done has been realised in the framework of several scientific seminars at the Department of "Machine Science, Machine elements, Engineering Graphics and Physics" at the Transport Faculty at the University of Ruse. The support is gratefully acknowledged.

\section{References}

[1] Niemann, G. \& Winter, H. (1983). Helical, bevel, worm, chain, belt, friction gear, clutches, brakes, freewheels, 2nd edn. Machine elements, vol 3. Springer, Berlin, Heidelberg, (Original title: Schraubrad-, Kegelrad-, Schnecken-, Ketten-, Riemen- Reibradgetriebe, Kupplungen, Bremsen, Freiläufe).

[2] Raspudic, V. (2020). Optimal Design of Laterally Unrestrained I-Beams Using Genetic Algorithm, Proceedings of the 31st DAAAM International Symposium, pp.0683-0691, B. Katalinic (Ed.), Published by DAAAM International, ISBN 978-3-902734-29-7, ISSN 1726-9679, Vienna, Austria DOI: 10.2507/31st.daaam.proceedings.095.

[3] Hrubina, K.; Katalinic, B.; Jadlovska, A.; Wessely, E.; Macurova, A. \& Majercak, J. (2010). Modeling and Computing Methods for Solving Optimization Problems, Chapter 42 in DAAAM International Scientific Book 2010, pp. 471-488, B. Katalinic (Ed.), Published by DAAAM International, ISBN 978-3-901509-74-2, ISSN 17269687, Vienna, Austria, DOI: 10.2507/daaam.scibook. 2010.42.

[4] Valjan, V. \& Raspudic, V. (2020). Stress and Fatigue Analysis of a Single Cylinder Engine Crankshaft, Proceedings of the 31st DAAAM International Symposium, pp.0692-0700, B. Katalinic (Ed.), Published by DAAAM International, ISBN 978-3-902734-29-7, ISSN 1726-9679, Vienna, Austria DOI: 10.2507/31st.daaam.proceedings.096.

[5] Trobradovic, M.; Blazevic, A.; Pikula, B. \& Bibic, D. (2020). Development of Simulation Model for Dry Clutch Engagement Analysis, Proceedings of the 31st DAAAM International Symposium, pp.0819-0825, B. Katalinic (Ed.), Published by DAAAM International, ISBN 978-3-902734- 29-7, ISSN 1726-9679, Vienna, Austria DOI: 10.2507/31st.daaam.proceedings.114.

[6] Likaj, R.; Bruqi, M.; Shala, A. \& Bajrami, X. (2016). Optimal Design and Analysis of Quarter Vehicle Suspension System by Using Matlab, Proceedings of the 27th DAAAM International Symposium, pp.0082-0090, B. Katalinic (Ed.), Published by DAAAM International, ISBN 978-3-902734-08-2, ISSN 1726-9679, Vienna, Austria, DOI: $10.2507 / 27$ th.daaam.proceedings.012. 
[7] Beles, H.; Rus, A.; Dragomir, G.; Mitran, T.; Trusca, D.\& Tolea, B. (2016). Researches Regarding the Continuous Improvement of the ABS (Anti-Lock Braking System) Operation for the Passenger Cars, Proceedings of the 26th DAAAM International Symposium, pp.0196-0205, B. Katalinic (Ed.), Published by DAAAM International, ISBN 978-3-902734-07-5, ISSN 1726-9679, Vienna, Austria, DOI:10.2507/26th.daaam.proceedings.027.

[8] Niemann, G. (1942). Worm gear with liquid friction - dependence of the transferable power and the coefficient of friction on tooth shape, dimensions, speed and lubricating viscosity. VDI publishing house, Berlin (Original title: Schneckentriebe mit flüssiger Reibung - Abhängigkeit der übertragbaren Leistung und des Reibwertes von Zahnform, Abmessung, Drehzahl und Schmierzähigkeit)

[9] Weber, C.; Maushake, W. \& Niemann, G. (1956). Investigation of cylindrical worm drives with axes crossing at right angles - Report 125 of the Research Center for Gears and Gear Construction Technical University of Munich. Vieweg + Teubner Verlag, Wiesbaden. (Original title: Untersuchung von Zylinderschneckentrieben mit rechtwinklig sich kreuzenden Achsen)

[10] Wilkesmann, H. (1974). Calculation of worm gears with different tooth profile shapes - load capacity and power loss for hollow circle, involute and straight line profile. Dissertation, Technical University of Munich, Munich. (Original title: Berechnung von Schneckengetrieben mit unterschiedlichen Zahnprofilformen - Tragfähigkeit und Verlustleistung für Hohlkreis-, Evolventen- und Geradlinienprofil)

[11] Predki, W. (1982). Hertzian pressures, lubrication gap heights and efficiency of worm drives. Dissertation, Ruhr University Bochum, Bochum. (Original title: Hertzsche Drücke, Schmierspalthöhen und Wirkungsgrade von Schneckentrieben)

[12] DIN 3996:2019-09: (2019). Load capacity calculation of cylindrical worm gears with axes crossing at 90 degree angles. (Original title: Tragfähigkeitsberechnung von Zylinder-Schneckengetrieben mit sich rechtwinklig kreuzenden Achsen).

[13] Bouché, B. (1991). Coefficients of friction of worm gear gears in the mixed friction area. Dissertation, Ruhr University Bochum, Bochum. (Original title: Reibungszahlen von Schneckengetriebeverzahnungen im Mischreibungsgebiet).

[14] AGMA 6034-B92: (2010). Practice for Enclosed Cylindrical Worm gear Speed Reducers and Gearmotors, AGMA, Alexandria, USA.

[15] Mott, R. L.; Vavrek, E. M. \& Wang, J. (2018). Machine Elements in Mechanical Design. 6th Ed. ISBN 10: 0-13444118-4 \& ISBN 13: 978-0-13-444118-4. Pearson Education, Inc., New York.

[16] Magyar, B. (2012). Tribo-dynamic investigations of cylindrical worm gears. Dissertation, Technical University of Kaiserslautern, Kaiserslautern. (Original title: Tribo-dynamische Untersuchungen von Zylinderschneckengetrieben).

[17] Oehler, M.; Magyar, B. \& Sauer, B. (2017). A new, standardizable calculation approach for the efficiency of worm gears. Research in Engineering 81 (2-3): 145-151. https://doi.org/10. 1007 / s10010-017-0225-1.(Original title: Ein neuer, normungsfähiger Berechnungsansatz für denWirkungsgrad von Schneckengetrieben. Forschung im Ingenieurwesen).

[18] Monz, A. (2012). Load capacity and efficiency of worm gears when lubricated with consistent gear greases. Dissertation, Technical University of Munich, Garching (Original title: Tragfähigkeit und Wirkungsgrad von Schneckengetrieben bei Schmierung mit konsistenten Getriebefetten).

[19] Mautner, E. M.; Sigmund, W.; Stemplinger J.P. \& Stahl, K. (2016). Efficiency of worm gearboxes. Proc Inst Mech Eng Part C: JMech Eng Sci 230(16):2952-2956.

[20] DIN 3996:2012-09: (2012). Load capacity calculation of cylindrical worm gears with axes crossing at 90 degree angles. (Original title: Tragfähigkeitsberechnung von Zylinder-Schneckengetrieben mit sich rechtwinklig kreuzenden Achsen).

[21] Oehler, M.; Magyar, B. \& Sauer, B. (2018). Coupled thermal and tribological analysis of worm gear. Tribol lubrication technology 65(1):54-60. (Original title: Gekoppelte thermische und tribologische Analyse von Schneckengetrieben).

[22] Oehler, M.; Magyar, B. \& Sauer, B. (2016). IGF-Nr. 18275N, FVANr. 729 I, Worm gear efficiency - worm gear efficiency. Final report, Frankfurt am Main. (Original title: Schneckengetriebewirkungsgrade Schneckengetriebewirkungsgrade).

[23] BS 721-1: (1963). Specification for Worm Gearing - Imperial Units, BSI, London, UK.

[24] Dobreva, A. (2013): Theoretical Investigation of the Energy Efficiency of Planetary Gear Trains. Mechanisms and Machine Science, No 13, pp 289-298.

[25] Dobreva, A. (2013). Methods for Improving the Geometry Parameters and the Energy Efficiency of Gear Trains with Internal Meshing. VDI - Berichte, No 2199.2, pp 1291 - 1302, (2013).

[26] Dobreva, A. \& Dobrev, V. (1993). Improving the Tribological Characteristics of Heavy Loaded Gear Boxes. Proceedings of the First Balkan Conference on Tribology "Balkantrib'93", Volume 2.3, Sofia, pp 166-170.

[27] Dobreva, A. \& Dobrev, V. (2018). Innovative Methodology for Decreasing Mechanical Losses in Vehicles. Proceedings of the 4th International Congress of Automotive and Transport Engineering (AMMA 2018), Springer Verlag, pp $234-242$.

[28] Dobreva, A. \& Stoyanov, S. (2012). Optimization Research of Gear Trains with Internal Meshing. Ruse, University Publishing Centre, pp 144. 